\title{
ROMANIAN BRANDS AWARENESS AMONG YOUNG PEOPLE. THE CASE OF COMMON FOOD PRODUCTS
}

\author{
Laura Cătălina Țimiraş, \\ "Vasile Alecsandri" University of Bacau, \\ timiras.laura@ub.ro
}

\begin{abstract}
Awareness is a prerequisite in the development of successful brands; in this paper are highlighted, for certain categories of common food products, brands enjoying the highest spontaneous awareness among young people. On the basis of this work are some of the results of a direct research conducted on a sample of 100 students, aged between 18 and 30 years. Common foods are intended for current consumption, serving to meet the dietary needs of consumers. Thus, we studied certain categories of food products with characteristics which make them fall within the common products category: milk and dairy products, meat and cooked meat (except fish), fish and eggs, canned meat (including pate), canned vegetables, bakery, milling products, pasta, breakfast cereals, sugar, eggs, nuts and seeds, oil, margarine. The conducted research has an exploratory character.
\end{abstract}

Keywords

brand, unassisted awareness, top of mind awareness, usual food products, Romanian market

\section{JEL Classification}

M31

\section{Introduction}

According to The Dictionary of American Marketing Association (2016), "Brand awareness is a marketing concept that enables marketers to quantify levels and trends in consumer knowledge and awareness of a brand's existence. At the aggregate (brand) level, it refers to the proportion of consumers who know the brand". (Source: The MASB Common Language Project. http://www.themasb.org/common-languageproject/ http://en.wikipedia.org/wiki/Brand_awareness"). Awareness refers both to the consumer's ability to recall and recognizes a brand; recall being achieved in the absence of the brand, and recognition in its presence (Datculescu, 2006). The importance of awareness is arising from the fact that to be purchased by consumers, a brand must first be known (Macdonald \& Sharp, 2003).

According to the Dictionary of Agromarketing, common foods are those products intended for current consumption and must have the following characteristics: have the best value for money; to be easily handled, stored and prepared, enabling time savings; to be nutritionally balanced so not to affect the health of consumers (Marian, 2016).

Basically, in this paper we have considered assessment of consumers' ability to recall (spontaneous awareness) different brands of food products just for that category of foods whose consumption is current. We therefore studied the following categories of food products that generally include foods that are categorized as common: milk and dairy products, meat and cooked meat (except fish), fish and eggs, canned meat (including pate), canned vegetables, bakery, milling products, pasta, breakfast cereals, sugar, eggs, nuts and seeds, oil and margarine.

Respondents were asked to indicate the top brands (max three) that come to mind when thinking about different groups of food products. Tables 1-15 show for each product 
category under investigation the brands mentioned by a minimum of five respondents (5\%) among first three known brands.

The research was exploratory one. The studied sample was made of 100 respondents, selected from the students of the Faculty of Economic Sciences, Vasile Alecsandri University of Bacau. The study was conducted in April 2016.

\section{Research results}

For a clearer picture of the place held by each brand in the minds of consumer, we have determined the number of respondents who indicated it in first place (top of mind), then the number of those who nominated it second place, respectively on the third place.

To assess the place of common products compared to the festive ones (consumer goods, occasionally consumed, with outstanding sensory properties, but containing substances whose regular consumption can be harmful), in terms of brand awareness, the first investigated aspect was to identify the most popular brands for the whole class of food products and alcoholic beverages (according to the methodology specified above).

Thus, in Table 1, that the most popular five brands, indicated by most of the respondents among the top three known are: Pambac, Coca Cola, Milka, Agricola, Fanta. Considering the first nominated brand, the brands situated in the top are: Pambac, Coca Cola, Milka, Fanta and Danone.

Note that Pambac stand out much from other brands both in terms of nominations among the top three popular brands and in terms of first nomination made by respondents. Thus, compared to the next ranked brands, over two times as many respondents indicated it both first and among the top three known brands.

Of the eleven brands indicated in Table 1, most of them are from soft drinks category (Coke, Fanta, Pepsi), chocolate category (Milka, Poiana) and dairy products category (Danone and Napolact). Also, one brand refers mainly to bakery, milling and pasta, one to meat and meat products, one to alcoholic beverages and one to fast food products. We therefore found that the awareness of the brand for the common products is much lower compared to the festive ones; only four (Pambac, Agricola, Danone and Napolact) of the eleven shown in Table. 1 referring in particular to the common food products.

Note that two of the brands presented in Table. 1, Pambac and Agricola, represent companies from Bacau county, where the study was conducted.

\section{Table no. 1. The most popular* brands of food products and alcoholic beverages on the Romanian market}

\begin{tabular}{|l|c|c|c|c|}
\hline \multirow{2}{*}{ Brand } & \multicolumn{2}{|c|}{$\begin{array}{c}\text { Share of respondents who indicated a particular } \\
\text { brand among the three that come to mind }\end{array}$} & $\begin{array}{c}\text { \% persons who } \\
\text { indicated brand } \\
\text { among the top 3 } \\
\text { known brands in } \\
\text { total number of } \\
\text { respondents }\end{array}$ \\
\cline { 2 - 5 } & $\begin{array}{c}\text { As first } \\
\text { option }\end{array}$ & $\begin{array}{c}\text { As second } \\
\text { option }\end{array}$ & $\begin{array}{c}\text { As third } \\
\text { option }\end{array}$ & 36 \\
\hline Pambac & 20 & 14 & 2 & 17 \\
\hline Coca Cola & 9 & 4 & 4 & 16 \\
\hline Milka & 9 & 5 & 2 & 13 \\
\hline Agricola & 4 & 8 & 1 & 12 \\
\hline Fanta & 6 & 5 & 1 & 11 \\
\hline Danone & 6 & 1 & 4 & 9 \\
\hline Napolact & 1 & 2 & 1 & 6 \\
\hline Pepsi & 2 & 1 & 3 & 5 \\
\hline Poiana & - & 1 & 4 & 5 \\
\hline Cotnari & 1 & 2 & 2 & 6 \\
\hline KFC & & & & \\
\hline
\end{tabular}




\begin{tabular}{|l|c|c|c|c|} 
Other answers & 33 & 48 & 58 & $\mathrm{X}$ \\
\hline Total & 96 & 94 & 88 & $\mathrm{X}$ \\
\hline
\end{tabular}

Following are the results referring to unassisted brand awareness for different categories of food products.

As regards milk and milk products, the first five places depending on the number of respondents who indicated them among the top three are: Zuzu, Napolact, La Dorna, Danone, Fulga; except Danone brand, all other brands are local. Considering the top of mind awareness, first five places are occupied by: Zuzu, La Dorna, Napolact, Fulga and Covalact, all Romanian. Over half of respondents indicated three brands of dairy products, $18 \%$ two brands, $25 \%$ one brand and $5 \%$ were not able to nominate any brand. Note that when studying the awareness of food products and alcoholic beverages brands, Danone was nominated by a greater number of respondents compared to Napolact (see table no. 1). But in the category of milk and milk products, Napolact outpaced by far Danone, especially in top of mind awareness. This shows a stronger association of the Napolact with the its product category compared to Danone, stronger mentally processed when the consumer thinks to food in general.

Table no. 2. The most popular* brands of milk and milk products on the Romanian market

\begin{tabular}{|c|c|c|c|c|}
\hline \multirow{2}{*}{ Brand } & \multicolumn{3}{|c|}{$\begin{array}{c}\text { Share of respondents who indicated a } \\
\text { particular brand among the top three that come } \\
\text { to mind }\end{array}$} & \multirow{2}{*}{$\begin{array}{l}\% \text { persons who } \\
\text { indicated brand } \\
\text { among the top } 3 \\
\text { known brands in } \\
\text { total number of } \\
\text { respondents }\end{array}$} \\
\hline & $\begin{array}{l}\text { As first } \\
\text { option }\end{array}$ & $\begin{array}{l}\text { As second } \\
\text { option }\end{array}$ & $\begin{array}{l}\text { As third } \\
\text { option }\end{array}$ & \\
\hline Zuzu & 21 & 10 & 7 & 38 \\
\hline Napolact & 13 & 9 & 4 & 26 \\
\hline La Dorna & 15 & 4 & 4 & 23 \\
\hline Danone & 3 & 10 & 6 & 19 \\
\hline Fulga & 12 & 3 & 2 & 17 \\
\hline Covalact & 6 & 4 & 3 & 13 \\
\hline Activia & 2 & 5 & 5 & 12 \\
\hline Panda & 4 & 3 & 4 & 11 \\
\hline Albalact & 3 & 4 & 2 & 9 \\
\hline Pilos & 3 & 3 & & 6 \\
\hline Casa Buna & & 3 & 3 & 6 \\
\hline Other answers & 13 & 12 & 12 & $\mathrm{X}$ \\
\hline Total & 95 & 70 & 52 & $\mathrm{X}$ \\
\hline
\end{tabular}

The best known brand of meat and meat products is Agricola, with a percentage of $35 \%$ from the perspective of top of mind awareness and with $42 \%$ of respondents who nominated it among the top three brands that they recall. Basically the number of respondents who indicated Agricola as the first brand of meat and meat products is almost 6 times higher than the next nominated brand (Fox). There is a relatively high share of those who could not nominate any brand in this category of products - 34\%, $31 \%$ indicating one brand, $22 \%$ two brands and only $13 \%$ mentioning three brands. All the six brands indicated by a minimum of 5 respondents are indigenous. 
Table no. 3. The most popular* brands of meat and meat products on the Romanian market

\begin{tabular}{|l|c|c|c|c|}
\hline \multirow{2}{*}{ Brand } & \multicolumn{2}{|c|}{$\begin{array}{c}\text { Share of respondents who indicated a } \\
\text { particular brand among the top three that come } \\
\text { to mind }\end{array}$} & $\begin{array}{c}\text { \% persons who } \\
\text { indicated brand } \\
\text { among the top 3 } \\
\text { known brands in } \\
\text { total number of } \\
\text { respondents }\end{array}$ \\
\cline { 2 - 5 } & $\begin{array}{c}\text { As first } \\
\text { option }\end{array}$ & $\begin{array}{c}\text { As second } \\
\text { option }\end{array}$ & $\begin{array}{c}\text { As third } \\
\text { option }\end{array}$ & 42 \\
\hline Agricola & 35 & 5 & 2 & 12 \\
\hline Fox & 6 & 5 & 1 & 9 \\
\hline Caroli & 3 & 5 & 2 & 9 \\
\hline Cristim & 4 & 3 & - & 6 \\
\hline Ana Si Cormel & 3 & 3 & - & 5 \\
\hline Kosarom & 2 & 3 & 7 & $\mathrm{X}$ \\
\hline Other answers & 13 & 11 & 13 & $\mathrm{X}$ \\
\hline Total & 66 & 35 & 1 & 9 \\
\hline
\end{tabular}

brands indicated by a minimum 5 respondents.

Source: own computation

The only fish and fish products brands that have minimum five nominations are Bonito and Salmaris (domestic brands). This category is characterized by a very low level of knowledge of brands; $72 \%$ of respondents indicating no brand.

Table no. 4. The most popular* brands of fish and fish products on the Romanian market

\begin{tabular}{|c|c|c|c|c|}
\hline \multirow{2}{*}{ Brand } & \multicolumn{3}{|c|}{$\begin{array}{c}\text { Share of respondents who indicated a } \\
\text { particular brand among the top three that come } \\
\text { to mind }\end{array}$} & \multirow{2}{*}{$\begin{array}{l}\text { \% persons who } \\
\text { indicated brand } \\
\text { among the top } 3 \\
\text { known brands in total } \\
\text { number of } \\
\text { respondents }\end{array}$} \\
\hline & $\begin{array}{l}\text { As first } \\
\text { option }\end{array}$ & $\begin{array}{l}\text { As second } \\
\text { option }\end{array}$ & $\begin{array}{l}\text { As third } \\
\text { option }\end{array}$ & \\
\hline Bonito & 11 & 2 & - & 13 \\
\hline Salamaris & 4 & - & 1 & 5 \\
\hline Other answers & 15 & 3 & 1 & $\mathrm{X}$ \\
\hline Total & 28 & 5 & 2 & $\mathrm{X}$ \\
\hline
\end{tabular}

* brands indicated by a minimum 5 respondents.

Source: own computation

In the category of canned meat and pate, Bucegi brand is first, with a share of $45 \%$ in top of mind and with $58 \%$ of those who indicated among first three brands. At a considerable distance are brands like: Mandy, Ardealul, Antefrig, Hame. Except Hame brand, all other brands are indigenous. The share of respondents who indicated one or more brands of canned meat and pate is relatively close compared to meat and meat products category. Thus, $33 \%$ could not even name one brand in this product category, $34 \%$ indicated one brand, $15 \%$ two brands and only $18 \%$ mentioned three brands.

Table no. 5. The most popular* brands of canned meat and pate on the Romanian market

\begin{tabular}{|c|c|c|c|c|}
\hline \multirow{2}{*}{ Brand } & \multicolumn{3}{|c|}{$\begin{array}{l}\text { Share of respondents who indicated a } \\
\text { particular brand among the top three that come } \\
\text { to mind }\end{array}$} & \multirow{2}{*}{$\begin{array}{l}\% \text { persons who } \\
\text { indicated brand } \\
\text { among the top } 3 \\
\text { known brands in total } \\
\text { number of } \\
\text { respondents }\end{array}$} \\
\hline & $\begin{array}{l}\text { As first } \\
\text { option }\end{array}$ & $\begin{array}{c}\text { As second } \\
\text { option }\end{array}$ & $\begin{array}{l}\text { As third } \\
\text { option }\end{array}$ & \\
\hline Bucegi & 45 & 9 & 4 & 58 \\
\hline Mandy & 5 & 6 & 3 & 14 \\
\hline
\end{tabular}




\begin{tabular}{|l|c|c|c|c|} 
Ardealul & 4 & 4 & 4 & 12 \\
\hline Antefrig & 2 & 2 & 1 & 5 \\
\hline Hame & - & 3 & 2 & 5 \\
\hline Other answers & 11 & 9 & 4 & $\mathrm{X}$ \\
\hline Total & 67 & 33 & 18 & $\mathrm{X}$ \\
\hline
\end{tabular}

* brands indicated by a minimum 5 respondents.

Source: own computation

Similar to the category of fish and fish products, for canned vegetables category there have been nominated by at least five respondents only two brands - Bonduelle and Cora; almost $70 \%$ of respondents were not able to identify any brand for this product group.

Table no. 6. The most popular* brands of canned vegetables on the Romanian market

\begin{tabular}{|c|c|c|c|c|}
\hline \multirow{2}{*}{ Brand } & \multicolumn{3}{|c|}{$\begin{array}{c}\text { Share of respondents who indicated a } \\
\text { particular brand among the top three that come } \\
\text { to mind }\end{array}$} & \multirow{3}{*}{$\begin{array}{c}\% \text { persons who } \\
\text { indicated brand } \\
\text { among the top } 3 \\
\text { known brands in } \\
\text { total number of } \\
\text { respondents } \\
17\end{array}$} \\
\hline & $\begin{array}{l}\text { As first } \\
\text { option }\end{array}$ & $\begin{array}{l}\text { As second } \\
\text { option }\end{array}$ & $\begin{array}{l}\text { As third } \\
\text { option }\end{array}$ & \\
\hline Bonduelle & 15 & 2 & - & \\
\hline Cora & 5 & 2 & - & 7 \\
\hline Other answers & 11 & 8 & 5 & $\mathrm{X}$ \\
\hline Total & 31 & 12 & 5 & $\mathrm{X}$ \\
\hline
\end{tabular}

* brands indicated by a minimum 5 respondents.

Source: own computation

Regarding bakery products, Pambac stand out much from other brands, being the first choice for $68 \%$ of respondents and ranking in the top three mentioned brands in the case of $79 \%$ of respondents. Ranked second both in top of mind and in terms of the first three nominations is Inan, brand belonging also to a producer from Bacau. Other brands mentioned by at least $5 \%$ of the respondents were: Franzeluţa, Boromir and Luca (the last two being also domestic brands).

Only $23 \%$ of all respondents indicated three brands in this product category, and $32 \%$ indicated two and one brand. A share of $13 \%$ did not indicate any brand in this product category.

Table no. 7. The most popular* brands of bakery products on the Romanian market

\begin{tabular}{|c|c|c|c|c|}
\hline \multirow{2}{*}{ Brand } & \multicolumn{3}{|c|}{$\begin{array}{c}\text { Share of respondents who indicated a } \\
\text { particular brand among the top three that come } \\
\text { to mind }\end{array}$} & \multirow{2}{*}{$\begin{array}{l}\% \text { persons who } \\
\text { indicated brand } \\
\text { among the top } 3 \\
\text { known brands in total } \\
\text { number of } \\
\text { respondents }\end{array}$} \\
\hline & $\begin{array}{l}\text { As first } \\
\text { option }\end{array}$ & $\begin{array}{l}\text { As second } \\
\text { option }\end{array}$ & $\begin{array}{l}\text { As third } \\
\text { option }\end{array}$ & \\
\hline Pambac & 68 & 9 & 2 & 79 \\
\hline Inan & 8 & 16 & 4 & 28 \\
\hline Franzeluţa & 2 & 6 & - & 8 \\
\hline Boromir & 1 & 4 & 1 & 6 \\
\hline Luca & 3 & 2 & - & 5 \\
\hline Other answers & 5 & 18 & 16 & $X$ \\
\hline Total & 87 & 55 & 23 & $X$ \\
\hline
\end{tabular}

* brands indicated by a minimum 5 respondents.

Source: own computation 
And in terms of milling products, Pambac was nominated by most respondents, both in terms of first nominated brand $(16 \%)$ and in terms of the first three nominated brands (19\%). Other brands indicated by a minimum of five respondents, but located at a considerable "distance" from the first are: Dobrogea, Cora and Grania, the latter also belonging to the company Pambac. A small number of respondents were able to nominate brands in this product category, $64 \%$ of them not doing any nomination.

Table no. 8. The most popular* brands of milling products on the Romanian market

\begin{tabular}{|c|c|c|c|c|}
\hline \multirow{2}{*}{ Brand } & \multicolumn{3}{|c|}{$\begin{array}{c}\text { Share of respondents who indicated a } \\
\text { particular brand among the top three that come } \\
\text { to mind }\end{array}$} & \multirow{2}{*}{$\begin{array}{l}\% \text { persons who } \\
\text { indicated brand } \\
\text { among the top } 3 \\
\text { known brands in } \\
\text { total number of } \\
\text { respondents }\end{array}$} \\
\hline & $\begin{array}{l}\text { As first } \\
\text { option }\end{array}$ & $\begin{array}{c}\text { As second } \\
\text { option }\end{array}$ & $\begin{array}{l}\text { As third } \\
\text { option }\end{array}$ & \\
\hline Pambac & 16 & 3 & - & 19 \\
\hline Dobrogea & 2 & 5 & - & 7 \\
\hline Cora & 5 & - & - & 5 \\
\hline Grania & 5 & - & - & 5 \\
\hline Other answers & 8 & 10 & 3 & $\mathrm{X}$ \\
\hline Total & 36 & 18 & 3 & $\mathrm{X}$ \\
\hline
\end{tabular}

Brand Pambac is in top for pasta, but was followed closely by Barilla, Italian brand. Of the respondents, only $8 \%$ indicated three possible answers, $18 \%$ two brands, and $34 \%$ one brand. $40 \%$ of them indicated no brand in this category.

Table no. 9. The most popular* brands of pasta products on the Romanian market

\begin{tabular}{|c|c|c|c|c|}
\hline \multirow{2}{*}{ Brand } & \multicolumn{3}{|c|}{$\begin{array}{l}\text { Share of respondents who indicated a } \\
\text { particular brand among the top three that come } \\
\text { to mind }\end{array}$} & \multirow{2}{*}{$\begin{array}{l}\% \text { persons who } \\
\text { indicated brand } \\
\text { among the top } 3 \\
\text { known brands in } \\
\text { total number of } \\
\text { respondents }\end{array}$} \\
\hline & $\begin{array}{l}\text { As first } \\
\text { option }\end{array}$ & $\begin{array}{l}\text { As second } \\
\text { option }\end{array}$ & $\begin{array}{l}\text { As third } \\
\text { option }\end{array}$ & \\
\hline Pambac & 24 & 6 & 1 & 31 \\
\hline Barilla & 21 & 9 & - & 30 \\
\hline Băneasa & 3 & 2 & 1 & 6 \\
\hline Other answers & 12 & 9 & 6 & $\mathrm{X}$ \\
\hline Total & 60 & 26 & 8 & $\mathrm{X}$ \\
\hline
\end{tabular}

Regarding breakfast cereals, the brands of the Swiss group Nestlé enjoys most awareness, respondents indicating either umbrella brand "Nestlé", either one of the product brands (Nesquik, Nestlé Fitness, Lion - presented in Table no. 13 and Cheerios and Cini Minis, indicated by fewer than five respondents). Thus, $47 \%$ of respondents indicated that first brand Nestlé or one of Nestlé group brands. Except Nestlé Group, only brand that accounted at least five nominations is Viva. Only $11 \%$ of all respondents indicated three brands of breakfast cereals, $21 \%$ indicated two brands and $35 \%$ one brand. $33 \%$ of respondents indicated no brand. 
Table no. 10. The most popular* brands of breakfast cereal products on the Romanian market

\begin{tabular}{|c|c|c|c|c|}
\hline \multirow{2}{*}{ Brand } & \multicolumn{3}{|c|}{$\begin{array}{c}\text { Share of respondents who indicated a } \\
\text { particular brand among the top three that come } \\
\text { to mind }\end{array}$} & \multirow{2}{*}{$\begin{array}{l}\% \text { persons who } \\
\text { indicated brand } \\
\text { among the top } 3 \\
\text { known brands in total } \\
\text { number of } \\
\text { respondents }\end{array}$} \\
\hline & $\begin{array}{l}\text { As first } \\
\text { option }\end{array}$ & $\begin{array}{l}\text { As second } \\
\text { option }\end{array}$ & $\begin{array}{l}\text { As third } \\
\text { option }\end{array}$ & \\
\hline Nestlé & 24 & 10 & 3 & 37 \\
\hline Nesquik & 16 & 6 & - & 22 \\
\hline Viva & 6 & 3 & - & 9 \\
\hline Nestlé Fitness & 3 & 4 & - & 7 \\
\hline Lion & 3 & 2 & - & 5 \\
\hline Other answers & 15 & 7 & 8 & $\mathrm{X}$ \\
\hline Total & 67 & 32 & 11 & $X$ \\
\hline
\end{tabular}

* brands indicated by a minimum 5 respondents.

Source: own computation

Known sugar brands to respondents are Mărgăritar and Coroniţa, both domestic. If Mărgăritar brand was nominated among the top three by a greater number of respondents, Coroniţa detaches far as first nominations (46\% of respondents). A relatively high number of respondents (14 people) nominated product by type ("granulated sugar"), not by brand, being registered in "other answers".

Table no. 11. The most popular* brands of sugar on the Romanian market

\begin{tabular}{|c|c|c|c|c|}
\hline \multirow[b]{2}{*}{ Brand } & \multicolumn{3}{|c|}{$\begin{array}{l}\text { Share of respondents who indicated a particular } \\
\text { brand among the top three that come to mind }\end{array}$} & \multirow{2}{*}{$\begin{array}{l}\% \text { persons who } \\
\text { indicated brand } \\
\text { among the top } 3 \\
\text { known brands in } \\
\text { total number of } \\
\text { respondents }\end{array}$} \\
\hline & $\begin{array}{l}\text { As first } \\
\text { option }\end{array}$ & $\begin{array}{l}\text { As second } \\
\text { option }\end{array}$ & $\begin{array}{l}\text { As third } \\
\text { option }\end{array}$ & \\
\hline Mărgăritar & 28 & 30 & 4 & 62 \\
\hline Coroniţa & 46 & 11 & 1 & 58 \\
\hline Other answers & 10 & 8 & 6 & $X$ \\
\hline Total & 84 & 49 & 11 & $\mathrm{X}$ \\
\hline
\end{tabular}

* brands indicated by a minimum 5 respondents.

Source: own computation

A lesser degree of knowledge was recorded for eggs, where only two brands - Agricola and Cora - accounted minimum five nominations (the first outpacing by far the second). It is found that $73 \%$ of respondents have not mentioned any brand in this category being practically the highest recorded percentage in this respect compared to the other categories of analyzed products.

Table no. 12. The most popular* brands of eggs on the Romanian market

\begin{tabular}{|c|c|c|c|c|}
\hline \multirow{2}{*}{ Brand } & \multicolumn{3}{|c|}{$\begin{array}{l}\text { Share of respondents who indicated a } \\
\text { particular brand among the top three that come } \\
\text { to mind }\end{array}$} & \multirow{2}{*}{$\begin{array}{l}\% \text { persons who } \\
\text { indicated brand } \\
\text { among the top } 3 \\
\text { known brands in } \\
\text { total number of } \\
\text { respondents }\end{array}$} \\
\hline & $\begin{array}{l}\text { As first } \\
\text { option }\end{array}$ & $\begin{array}{c}\text { As second } \\
\text { option }\end{array}$ & $\begin{array}{l}\text { As third } \\
\text { option }\end{array}$ & \\
\hline Agricola & 17 & - & - & 17 \\
\hline Cora & 4 & 1 & - & 5 \\
\hline Other answers & 6 & 2 & 2 & $\mathrm{X}$ \\
\hline Total & 27 & 3 & 2 & $\mathrm{X}$ \\
\hline
\end{tabular}

* brands indicated by a minimum 5 respondents.

Source: own computation 
Seeds and nuts category is dominated in terms of brand awareness by Nutline, a domestic brand, registering a $37 \%$ in the case of top of mind awareness. The share of those who have made three nominations in this category of products was $9 \% ; 27 \%$ had two nominations and $32 \% 3$ nominations. $32 \%$ of respondents could not recall any brand in the analyzed category.

Table no. 13. The most popular* brands of seeds and nuts on the Romanian market

\begin{tabular}{|c|c|c|c|c|}
\hline \multirow[b]{2}{*}{ Brand } & \multicolumn{3}{|c|}{$\begin{array}{l}\text { Share of respondents who indicated a particular } \\
\text { brand among the top three that come to mind }\end{array}$} & \multirow{2}{*}{$\begin{array}{l}\% \text { persons who } \\
\text { indicated brand } \\
\text { among the top } 3 \\
\text { known brands in } \\
\text { total number of } \\
\text { respondents }\end{array}$} \\
\hline & As first option & $\begin{array}{l}\text { As second } \\
\text { option }\end{array}$ & $\begin{array}{l}\text { As third } \\
\text { option }\end{array}$ & \\
\hline Nutline & 37 & 10 & 1 & 48 \\
\hline Grivas & 8 & 8 & 1 & 17 \\
\hline Star & 2 & 3 & 1 & 6 \\
\hline Other answers & 21 & 15 & 6 & $\mathrm{X}$ \\
\hline Total & 68 & 36 & 9 & $X$ \\
\hline
\end{tabular}

In the category of oil, the best known brands, as indicated by most respondents among the top three nominees, are: Untdelemn de la Bunica and Unisol, both domestic; the first of them holding a $30 \%$ share in the case of top of mind. Out of 100 respondents, 11 indicated three oil brands, 27 two brands and 36 one brand. 26 respondents could not recall any brand of oil.

Table no. 14. The most popular* oil brands on the Romanian market

\begin{tabular}{|c|c|c|c|c|}
\hline \multirow{2}{*}{ Brand } & \multicolumn{3}{|c|}{$\begin{array}{c}\text { Share of respondents who indicated a } \\
\text { particular brand among the top three that come } \\
\text { to mind }\end{array}$} & \multirow{2}{*}{$\begin{array}{l}\% \text { persons who } \\
\text { indicated brand } \\
\text { among the top } 3 \\
\text { known brands in total } \\
\text { number of } \\
\text { respondents }\end{array}$} \\
\hline & $\begin{array}{l}\text { As first } \\
\text { option }\end{array}$ & $\begin{array}{l}\text { As second } \\
\text { option }\end{array}$ & $\begin{array}{l}\text { As third } \\
\text { option }\end{array}$ & \\
\hline $\begin{array}{l}\text { Untdelemn de la } \\
\text { bunica }\end{array}$ & 30 & 6 & 1 & 37 \\
\hline Unisol & 20 & 15 & 2 & 37 \\
\hline Aro & 4 & 1 & 1 & 6 \\
\hline Floriol & 3 & & 2 & 5 \\
\hline Other answers & 17 & 16 & 5 & $X$ \\
\hline Total & 74 & 38 & 11 & $X$ \\
\hline
\end{tabular}

* brands indicated by a minimum 5 respondents.

Source: own computation

The best known brand of margarine is Delma, being the first nominated by $60 \%$ of respondents. At considerable "distance" have been nominated Rama, Unirea and Becel. $11 \%$ of all respondents indicated three brands of margarine, $27 \%$ two brands and $44 \%$ one brand.

Table no. 15. The most popular* brands of margarine on the Romanian market

\begin{tabular}{|c|c|c|c|c|}
\hline \multirow[t]{2}{*}{ Brand } & \multicolumn{3}{|c|}{$\begin{array}{l}\text { Share of respondents who indicated a } \\
\text { particular brand among the top three that come } \\
\text { to mind }\end{array}$} & \multirow{2}{*}{$\begin{array}{l}\% \text { persons who } \\
\text { indicated brand } \\
\text { among the top } 3 \\
\text { known brands in tota }\end{array}$} \\
\hline & $\begin{array}{l}\text { As first } \\
\text { option }\end{array}$ & $\begin{array}{l}\text { As second } \\
\text { option }\end{array}$ & As third option & \\
\hline
\end{tabular}




\begin{tabular}{|l|c|c|c|c|}
\cline { 2 - 5 } & & & & \multicolumn{2}{c|}{$\begin{array}{c}\text { number of } \\
\text { respondents }\end{array}$} \\
\hline Delma & 60 & 12 & 3 & 75 \\
\hline Rama & 9 & 10 & 4 & 23 \\
\hline Unirea & 5 & 5 & 1 & 11 \\
\hline Becel & 2 & 4 & - & 6 \\
\hline Other answers & 6 & 7 & 3 & $\mathrm{X}$ \\
\hline Total & 82 & 38 & 11 & $\mathrm{X}$ \\
\hline
\end{tabular}

* brands indicated by a minimum 5 respondents.

Source: own computation

\section{Conclusions}

The results of research conducted among students of the Faculty of Economic Sciences of the Vasile Alecsandri University of Bacau regarding the awareness of common food products shows a relatively low degree of their knowledge. For certain categories of products - eggs, fish and fish products, canned vegetables, grain mill - the share of those who remembered no brands was between $64 \%$ and $73 \%$; and for categories: pasta, meat and meat products, breakfast cereals, canned meat and pate, nuts and seeds, oil, over $25 \%$ of respondents could not indicate any brand, even if some of these groups occupy a significant share in alimentation, according to the food pyramid (Graur, 2006).

Referring to the brands of food products and alcoholic beverages which enjoys the highest awareness among young people, the results of the study highlight the greater degree of knowledge of brands for festive goods (whose consumption is occasional) compared to the common food products. Determined based on the number of respondents who have nominated them between the first three recalled brands, Pambac, Coca-Cola, Milka, Agricola, Fanta enjoy the highest value of awareness, and for the top of mind the first brands are: Pambac (20\%), Coca Cola and Milka (both 9\%), Fanta and Danone (both 6\%).

By product category, brands with the highest share in terms of top of mind awareness in the examined sample are: Zuzu (21\%) for milk and dairy products, Agricola for meat and cooked meat, except fish (35\%) and eggs (17\%), Bonito (11\%) for fish and fish products, Bucegi (45\%) for canned meat products, including pate, Bonduelle (15\%) for canned vegetable, Pambac for: bakery products $(68 \%)$, milling products $(16 \%)$, pasta (24\%), Nestlé (47\%, including both umbrella brand Nestlé and brands of product: Nestlé Nesquik, Nestlé Fitness Nestlé Lion, Nestlé Cheerios and Nestlé Cini Minis) for cereal for breakfast, Coroniţa (46\%) for sugar, Nutline (37\%) for nuts and seeds, and Untdelemn de la bunica (30\%) for oil and Delma (60\%) for margarine.

Low level of knowledge of the brands for the various categories of food products from those studied should be a warning to operators in the respective markets; as mentioned at the start of the paper, the awareness of the product / brand is a basic condition for its acquisition. In this context, the study results can form hypotheses for research on nationally representative samples, through which could be obtained necessary information on which can be adopted decisions to improve communication to increase awareness of the brands portfolio.

\section{References}

Dătculescu, P. (2012), Cercetarea practică de marketing, Editura Brandbuilders Grup, Bucureşti.

Dătculescu, P. (2006), Cercetarea de marketing, Editura Brandbuilders Grup, Bucureşti.

Fifield, P (2008), Marketing Strategy Masterclass. Implementing Marketing Strategy, Elsevier.

Graur M. (coord.), (2006), Ghid pentru alimentaţia sănătoasă, Editura Performatica, Iaşi, available at http://www.fao.org/3/a-as693o.pdf. 
Macdonald E, Sharp B. (2003), Management Perceptions of the Importance of Brand Awareness as an Indication of Advertising Effectiveness, Marketing Bulletin, no. 14, Article 2, available at http://marketingbulletin.massey.ac.nz/V14/MB V14_A2 Macdonald.pdf.

Manole, V., Stoian M., Ion, R.A. (2003), Agromarketing, Ediţia a II-a, Editura ASE, Bucureşti.

Marian, C., (2016), Dicţionar de agromarketing, Editura Tribuna Economică, Bucureşti.

Săndulescu L. (2015, September, 18), Top 100 cele mai puternice branduri romanesti, Revista Biz available at http://www.revistabiz.ro/top-100-cele-mai-puternicebranduri-romanesti/.

Ţimiraş, L. (2016), Young People's Preferences For Romanian Agro Alimentary Goods, Studies and Scientific Researches. Economics Edition, Special Issue, available at: http://sceco.ub.ro/index.php/SCECO/article/view/353.

American Marketing Association (2016), Dictionary, available at https://www.ama.org/resources/Pages/Dictionary.aspx?dLetter=B.

Revista Piața (2008, Iunie, 21), Brandul romanesc fata cu globalizarea, available at: http://www.revista-piata.ro/Marci_romanesti-id168.html. 